\title{
En ung mann med mononukleose og hevelse over høyre øye
}

En 19-åring med mononukleose utviklet hevelse over høyre orbita. Han ble innlagt på lokalsykehus og etter hvert overflyttet til regionsykehus på grunn av økende symptomer trass i behandling med intravenøs antibiotika.

Se kommentar side 37 og kunnskapsprøve på www.tidsskriftet.no/quiz

\section{Nils Petter Wold Fossland}

nils.petter.fossland@stolav.no

Vegard Bugten

Ståle Nordgård

$\emptyset$ Øre-nese-hals-avdelingen

Karin Aasly

Øyeavdelingen

St. Olavs hospital

Olav Kyrres gate 17

7006 Trondheim

En 19 år gammel mann ble innlagt ved sitt lokalsykehus etter at han utviklet hevelse over høyre øyeregion. Han hadde tre uker før dette fått positivt prøvesvar på hurtigtest for mononukleose og hadde vært i dårlig allmenntilstand uken før innleggelse. Ved innkomst var han høyfebril med temperatur $41^{\circ} \mathrm{C}$, sløv og trett. CRP var over 160. Han hadde forstørret lever og milt ved palpasjon og generalisert lymfeknutesvulst. Han hadde puss i nasopharynx ved inspeksjon i svelget. Han anga ikke hodesmerter ved direkte forespørsel. Mottakende indremedisiner vurderte øyebevegelse som normal, men fant proptose av høyre bulbus oculi. Det ble igangsatt antibiotikabehandling med penicillin 2 mill IE. 6 intravenøst, gentamicin $630 \mathrm{mg} \cdot 1 \mathrm{in}$ travenøst og metronidazol $500 \mathrm{mg} \cdot 2$ peroralt. Tentativ diagnose var sepsis utgående fra bihulene som komplikasjon til mononukleose. Det ble dagen etter innkomst tatt MR caput som viste slimhinnefortykkelser i bihulene og et infiltrat i høyre orbita. Man så et mulig væskelokulament helt basalt fortil $i$ fremre skallegrop på høyre side, og med dertil mistanke om meningittutvikling. I tillegg ble det sett ødemforandringer i omliggende vev som bar preg av inflammasjon.

Det ble tidlig i forløpet rekvirert MR caput. Det er ingen informasjon om eventuell nakkestivhet i epikrisen. Vi antar likevel at MR caput ble tatt for å kartlegge eventuell intracerebral infeksjon. $ø$ dem. Fremre og bakre rhinoskopi viste ikke påfallende sekresjon i nesekaviteten. Det ble funnet oppvekst av betahemolytiske streptokokker som var sensible for penicillin, og gramnegative staver som var sensible for metronidazol $i$ blodkultur. To dager etter oppstart av behandling hadde CRP falt fra 200 til 100, men fire dager etter innkomst var CRP økt til 155. Det ble tatt CT av bihuler uten kontrast som viste pansinusitt og orbital hevelse som presset bulbus oculi utover (fig 1).

Pasienten fikk økende hevelse over øyet og i øyelokket til tross for antibiotikabehandling, og CT viste pansinusitt. Tentativ diagnose var begynnende periorbital abscess. Lokalsykehuset ønsket vurdering av indikasjon for bihulekirurgi og videre antibiotikabehandling. Pasienten ble overflyttet til regionsykehuset for å kunne nytte kompetanse fra avdelinger for øre-nese-hals, øye og eventuelt infeksjonsmedisin.

Etter ankomst regionsykehuset ble behandlingen endret etter tilsyn fra infeksjonsmedisiner. Ciprofloksacin $500 \mathrm{mg} \cdot 2$ intravenøst

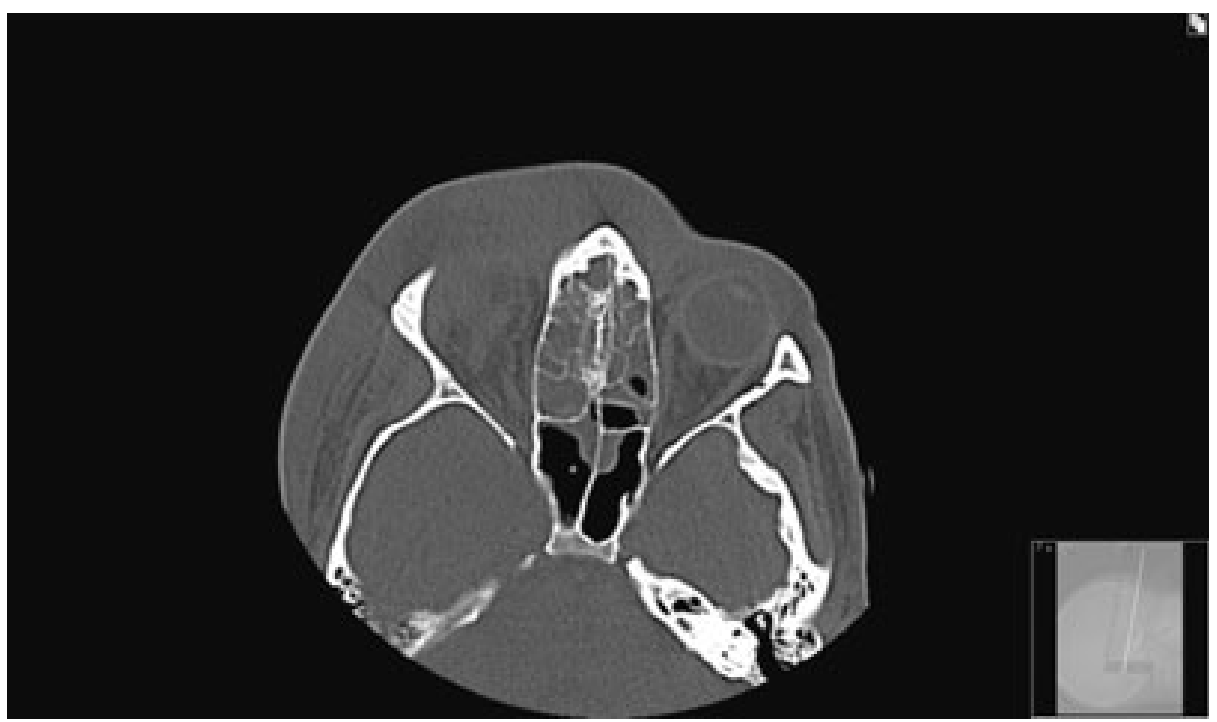

Figur 1 CT uten kontrast viser betydelige fortetninger i alle sinuser, bløtdelshevelse/cellulitt i høyre orbitaregion og intraorbitalt høyre side med påfølgende proptose av høyre bulbus oculi erstattet gentamycin, da gentamycin har dårlig effekt ved abscesser. I tillegg økte man dosen penicillin fra 2 mill IE til 4 mill IE . 6 og metronidazol fra $500 \mathrm{mg} \cdot 2 \mathrm{til} 500 \mathrm{mg} \cdot 3$ intravenøst. CT av bihuler med kontrast viste nå abscess fra pannen og inn i mediale øyevinkel (fig 2). I tillegg så man orbital cellulitt som dislokerte bulbus frem og ned og ga pasienten en kraftig proptose av høyre øye. Det var også en kontrastoppladende oppfylning medialt oppad og baktil for bulbus.

Det var en klar progrediering av hevelsen periorbitalt, fra periorbitalt ødem til periorbital abcess. Konservativ behandling av infeksjonen hadde ikke nådd frem, og det var derfor indikasjon for operativ behandling.

Pasienten ble operert samme kveld. Den periorbitale abscessen ble tømt, og det ble sydd fast et bølgedren. Det ble deretter gjort bilateral åpning av fremre etmoidalsinus og antrostomi til maxillarsinus. Vi fant store mengder puss $i$ alle sinuser. Dyrkning av bakterieundersøkelse fra lokalsykehus viste oppvekst av anaerobe staver.

Man mistenkte infeksjon med fusobacterium og utvikling av Lemierres syndrom.

Det ble gjort ultralyd av hals neste dag for å utelukke halsvenetrombose, men det var normale funn. Exophthalmus gikk tilbake, men det tilkom økende retrobulbære smerter to dager etter drenasje. Øyelegetilsyn 


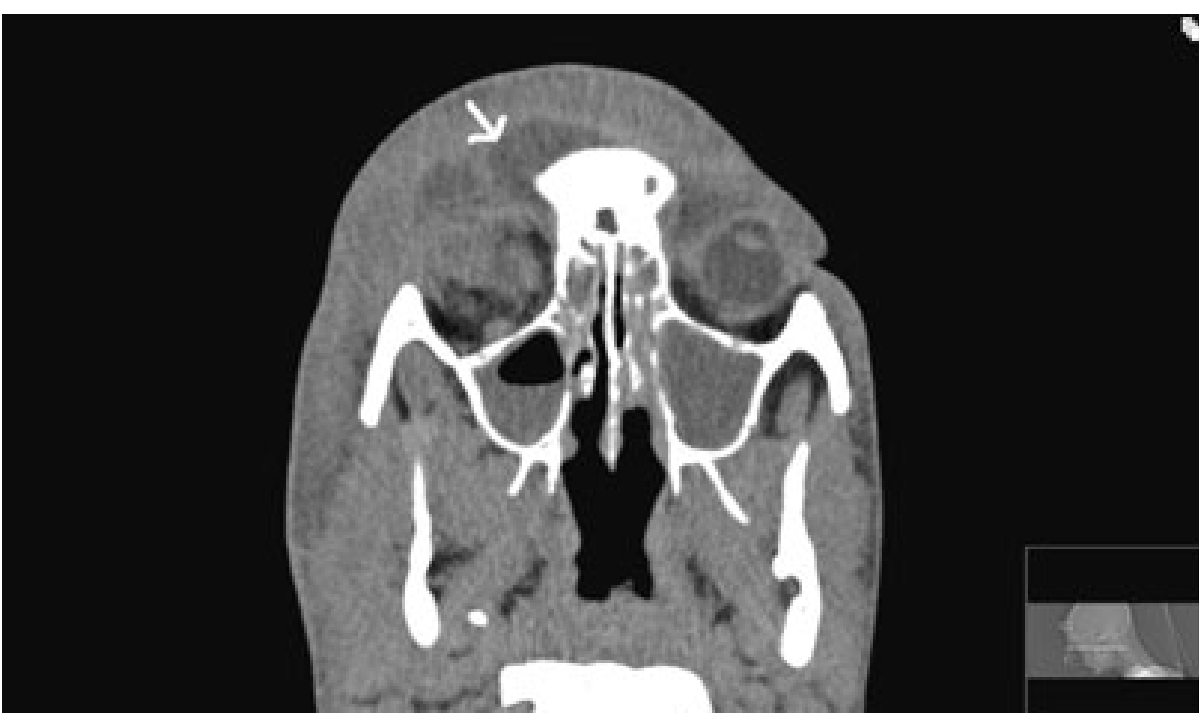

Figur 2 Abscessutvikling sett på CT med kontrast tatt etter ankomst regionsykehuset

viste papilleforandringer som tegn på økende press på eller traksjon av nervus opticus og innskrenket bevegelighet av øyet. Ny CT ble tatt. Det var tilbakegang av abscess i panneregionen, men fortsatt et lavattenuerende område like over høyre øye. Det lavattenuerende området ble ikke eksplorert ved første operasjon, da man mente at abscessen kommuniserte med området. Det gjorde den ikke.

Det ble nå gjort eksplorativ orbitotomi på høyre side med drenasje av intraorbital abscess. Periorbita ble løsnet medialt i orbitataket, orbitainnhold ble mobilisert nedover og periorbita bak bulbus ble åpnet. Man kom inn $i$ en ny abscesshule og det ble lagt inn enda et bølgedren, denne gang intraorbitalt over bulbus oculi. Postoperativt viste øyelegetilsyn bedre øyebevegelighet, og pasienten hadde fallende infeksjonsparametre.

Operasjonen ble vurdert som vellykket.

To dager etter andre operasjon hadde pasienten økende retrobulbære smerter over høyre øye. Ny CT-undersøkelse med kon- trast viste økning av abscess bak bulbus occuli, mellom nervus opticus og musculus rectus medialis (fig 3 ).

Abscessen var vanskelig å nå gjennom ørenese-hals-tilgang og vi tok derfor kontakt med Øyeavdelingen for samarbeid.

Ny operasjon ble gjennomført, nå sammen med øyelege (fig 4). Conjunctiva ble løsnet medialt mot bulbus og man gikk stumpt bakover til man traff på abscessen mellom mediale rectusmuskulatur og nervus opticus (fig 5). Vi gikk deretter inn i de to foregående abscesshulene, skylte godt og la inn to nye bølgedren. Denne gang normaliserte infeksjonsprøvene seg umiddelbart, og kliniske symptomer gikk raskt i regress. Kontroll-CT med kontrast to dager postoperativt viste na ingen tegn til abscess. Bakterieundersøkelse med resistensbestemmelse av den første abscessen viste oppvekst av Streptococcus anginosus (Milleri), en abscessogen mikrobesom var sensitiv for penicillin $G$, og vekst av Fusobacterium necroforum (anaerob), som

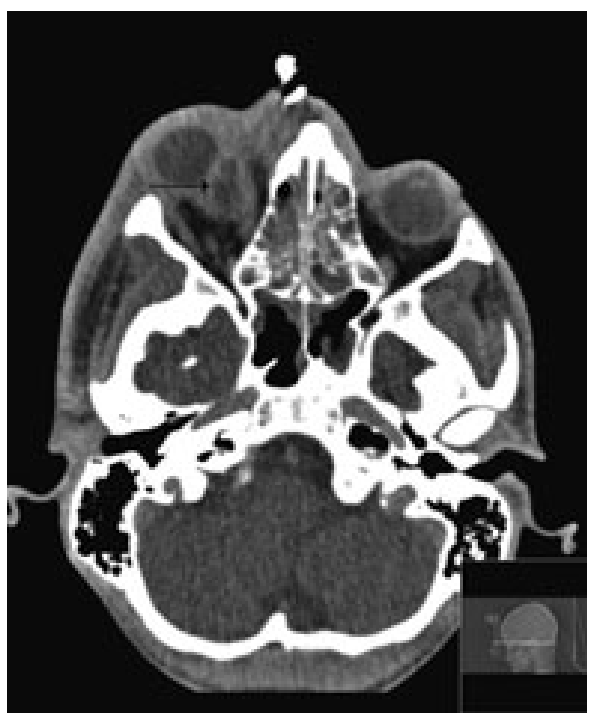

Figur 3 Intraorbital abscess mellom musculus rectus medialis og nervus opticus

var sensitiv for metronidazol. Ciprofloksacin ble seponert. Alle dren ble fjernet to dager etter siste operasjon. Synet normaliserte seg, proptosen gikk tilbake og konjunktival blandingsinjeksjon ble behandlet med kloramfenikol salve $i$ en uke. Han ble utskrevet, og videre kontroller skjedde på pasientens lokalsykehus. Ved telefonisk kontakt med pasienten ett år senere hadde han ingen sekveler etter sykdomsforløpet.

\section{Diskusjon}

Rhinosinusitt er en helsemessig utfordring. Behandlingsmessig står akutte infeksjoner i de øvre luftveier for en betydelig samfunnsutgift. Det ble registrert 11495 liggedøgn for akutte infeksjoner i luftveiene i 2008 , influensasykdom og lungebetennelse ekskludert (1). Akutt bakteriell rhinosinusitt (ABRS) defineres som inflammasjon i nese og de paranasale sinuser karakterisert ved nesetetthet eller renning fra nesen. I tillegg har man enten redusert luktesans og/eller ansiktssmerter. Ved varighet over 12 uker har man utviklet kronisk rhinosinusitt (2).

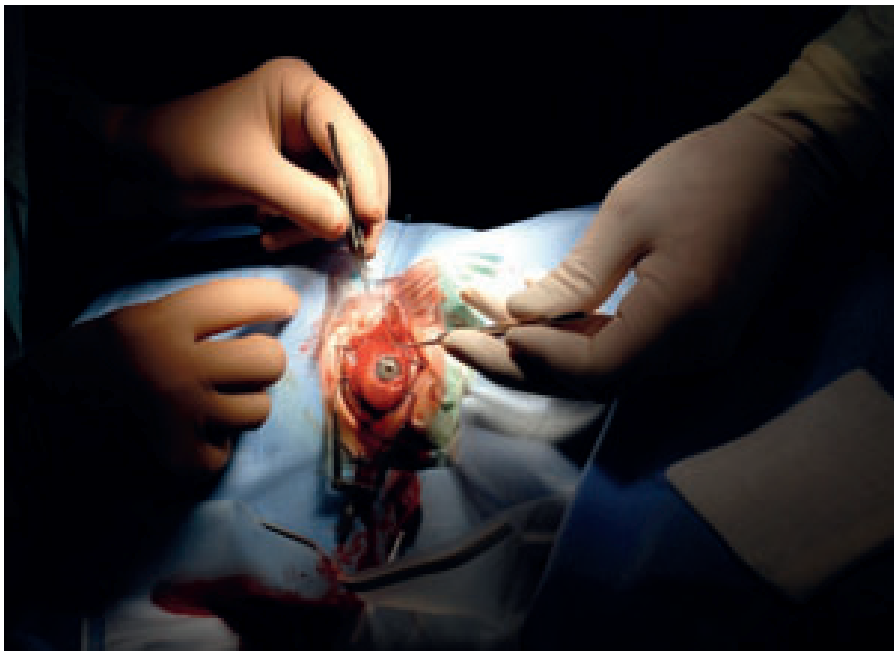

Figur 4 Løsning av conjunctiva for evakuering av retrobulbær abscess

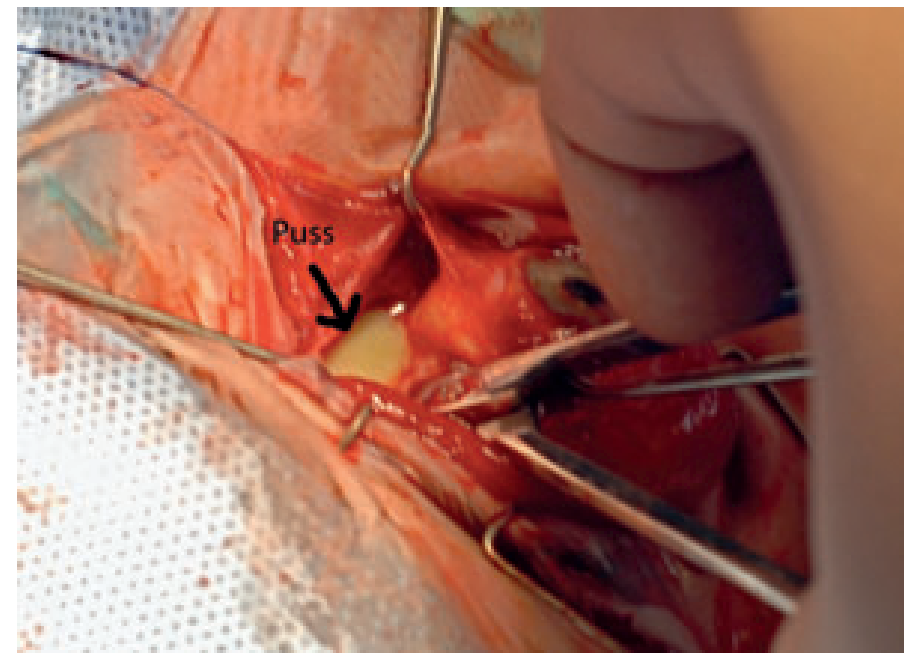

Figur 5 Abscessen funnet, man spriker med peang retrobulbært 
Vår pasients sykehistorie med intraorbital komplikasjon til akutt rhinosinusitt er uvanlig. Totalt ble det på somatiske sykehus i Norge registrert 71 døgnopphold for alvorlige akutte øyeinfeksjoner i 2008 (3). Antallet intraorbitale abscesser ligger innenfor denne gruppen. Spredning av bakteriell infeksjon fra maksillær-, etmoidal-, sfenoidal- og frontalsinus kan skje via to ruter (4):

- Direkte gjennom åpne suturlinjer eller foramina, erosjon av beinbarrierer, da særlig lamina papyracea.

- Via retrograd tromboflebitt gjennom nettverket av klaffeløse vener som gir fri kommunikasjon mellom orbita og ansikt, nesekavitet og sinus med orbita.

Det er ingen lymfedrenasje i området, så det skjer ingen lymfogen spredning av infeksjon. E-figur 6 viser en skjematisk oversikt over orbitale komplikasjoner, satt opp etter økende alvorlighetsgrad.

Ved diagnostikk av orbitainfeksjon er ikke CT nødvendig ved ren periorbital cellulitt. Man kan behandle ut ifra kliniske funn og prøvesvar. Men dette kan i praksis være vanskelig å vurdere. CT med kontrast skal tas dersom man mistenker postseptal infeksjon eller hvis man ikke får klinisk bedring etter 24 timer med medikamentell behandling. Ved mistanke om intrakranial komplikasjon, sinus cavernosus-trombose, intrakranial abscess, subduralt empyem og meningisme gir MR bedre diagnostisk informasjon enn CT.

Vår pasient hadde oppvekst av F necroforum og $\mathrm{S}$ anginosus. $\mathrm{F}$ necroforum er en gramnegativ, anaerob, stavformet potensielt virulent bakterie som kan gi nekrotisk, puru- lent infeksjon hos både mennesker og dyr. Bakterien er isolert i flere sykdomstilstander hos særlig barn og unge. Den kan finnes i peritonsillære abscesser, parafaryngeale abscesser, orbitaabscesser og hos pasienter med meningitt $(5,6)$. Orbitainfeksjoner med $\mathrm{F}$ necroforum gir et aggressivt klinisk bilde med behov for tidlig kirurgisk intervensjon, som tilfellet var hos vår pasient (5-7).

F necroforum er hovedpatogenet i Lemierres syndrom, en sjelden tilstand som består av orofaryngeal sepsis, trombose i vena jugularis og metastatiske abscesser funnet oftest i lunger, rørknokler og ledd (8).

I behandling av pasienter med mononukleose bør man være oppmerksom på superinfeksjoner, da mononukleose induserer en viss grad av immunsuppresjon. EpsteinBarr-virus (EBV) gir et forbigående fall i Tcellemediert immunitet, som kan predisponere for en bakteriell superinfeksjon. Epstein-Barr-virusinfeksjon er svært vanlig, mens invasiv fusobacteriuminfeksjon er sjelden. Det er en klar overlapping i insidenstopp for Epstein-Barr-virusinfeksjon og invasiv $\mathrm{F}$ necroforum-infeksjon, men flere undersøkelser må til for å bekrefte sammenhengen mellom disse tilstandene (8).

Intraorbitale og intrakraniale komplikasjoner til rhinosinusitt er uvanlig, men det er viktig å gi rask og korrekt behandling for å hindre synstap, intrakraniale sekveler eller død. Rask oppstart av intravenøs antibiotikabehandling er viktig for at tilstanden ikke skal progrediere. Ved utilfredsstillende effekt av medikamentell behandling med abscessutvikling skal terskelen for kirurgisk intervensjon med intraorbital eksplorasjon og drenasje av abscess være lav.
Pasienten har gitt samtykke til at artikkelen blir publisert.

Oppgitte interessekonflikter: Ingen

e-fig 6 finnes i artikkelen på www.tidsskriftet.no

\section{Litteratur}

1. Statistisk sentralbyrå. Døgnopphold, dagbehandlinger og liggedager ved somatiske sykehus, etter kjønn, alder og diagnose. 2008. Sykdommer i de øvre luftveisinfeksjoner.

http://statbank.ssb.no/statistikkbanken/ Default FR.asp?PXSid=0\&nvl=true \&PLanguage $=$ $0 \&$ tilside $=$ selecttable/hovedtabellHjem.asp\& KortnavnWeb=pasient (16.9.2910)

2. Fokkens W, Lund V, Mullol J. European position paper on rhinosinusitis and nasal polyps 2007. Rhinol Suppl 2007; nr. 20: 1-136.

3. Statistisk sentralbyrå. Døgnopphold, dagbehandlinger og liggedager ved somatiske sykehus, etter kjønn, alder og diagnose. 2008. Sykdommer i øyet og øyets omgivelser. http://statbank.ssb.no/ statistikkbanken/Default FR.asp?PXSid=0\&nvl= true \&PLanguage $=0 \&$ tilside $=$ selecttable $/$ hovedtabellHjem.asp\&KortnavnWeb=pasient (16.9.2910).

4. Kennedy DW, Bolger WE, Zinreich SJ. Diseases of the sinuses. Diagnosis and management. Hamilton, Ontario: B.C. Decker, 2001

5. Rusan M, Klug TE, Ovesen T. An overview of the microbiology of acute ear, nose and throat infections requiring hospitalisation. Eur J Clin Microbiol Infect Dis 2009; 28: 243-51.

6. Pitkäranta A, Lindahl $P$, Raade $M$ et al. Orbital abscess caused by Fusobacterium necrophorum Int J Pediatr Otorhinolaryngol 2004; 68: 585-7.

7. Ralli M, Taban M, Mancini R et al. Orbital abscesses caused by Fusobacterium necrophorum. Ophthal Plast Reconstr Surg 2009; 25: 70-2.

8. Brazier JS. Human infections with Fusobacterium necrophorum. Anaerobe 2006; 12: 165-72.

Mottatt 3.12. 2009, første revisjon innsendt

15.2. 2010, godkjent 16.9. 2010.

Medisinsk redaktør Michael Bretthauer.

\section{Kommentar}

\section{Mitt og ditt fag}

Økt spesialisering preger moderne medisin. Dette gir mer spisskompetanse, men mindre breddekompetanse. En side av dette er mer revirtenkning. Faget blir delt opp i mitt og ditt. De som er gode på noe, får et eierforhold til akkurat det fagområdet og påberoper seg retten til å være de eneste som skal drive med det. Dette er ikke nødvendigvis en fordelaktig utvikling for den enkelte pasient. Også innen medisinen er det en økende erkjennelse av at alt henger sammen med alt. Det kan være et motsetningsforhold mellom dette og det at stadig flere kan mindre og mindre om mer og mer.

Økt samarbeid mellom spesialister er en måte å møte denne utfordringen på. Det bidrar til høy totalkompetanse i behand- lingsforløpet og sikrer at alle pasientens behov blir ivaretatt. Artikkelen «En ung mann med mononukleose og hevelse over høyre øуе» av Nils Petter Wold Fossland og medarbeidere beskriver akkurat dette. En rekke spesialister ved et regionsykehus samarbeidet tett omkring en pasient med en potensielt livstruende sykdom og sikret at han ble frisk. Dette er et eksempel til etterfølgelse. I utgangspunktet burde tverrfaglig samarbeid på sykehus være enkelt å få til. Det finnes imidlertid elementer i dagens sykehuspolitikk som gjør at det en del steder er vanskelig. Funksjonsfordeling mellom sykehus kan innebære at spesialister som trengs $i$ et behandlingsteam, er spredd på ulike steder. Endringer i sykehusstruktur innebærer at ressurser flyttes. Noen får og andre mister. Det finnes en rekke eksempler på at dette skaper dårlig samarbeidsklima mellom kolleger. Slike forhold er det viktig å ta hensyn til når fremtidens helsevesen planlegges, til det beste både for pasienter, fagfolk og begrensede ressurser.

\section{Sverre Steinsvåg}

sverre.steinsvag@sshf.no

$\emptyset$ re-nese-hals-avdelingen

Sørlandet Sykehus

4604 Kristiansand

Oppgitte interessekonflikter: Ingen 